\title{
GPX3 Gene
}

National Cancer Institute

\section{Source}

National Cancer Institute. GPX3 Gene. NCI Thesaurus. Code C127002.

This gene is involved in the metabolism of hydrogen peroxide and lipid peroxides. 